of Robbins and Schmidt ${ }^{7-76}$ and Bonner ${ }^{78}$. This resulted in a sharp increase for the following year to a level of $12 \cdot 6 \pm 0.8 \mathrm{~mm}$. The increase here, over the previous mean rate, was $+6 \cdot 1+0 \cdot 8$, hence highly significant. This last nutrient has been used for too short a time (54 passages) to establish a new seasonal cycle. The results so far suggest, however, that the seasonal cycle may become much less pronounced in this nutrient. The impression given is that the great number of nutrient materials available and the more nearly optimal complex of environmontal conditions provide a buffer against the injurious effects of certain variables, especially temperature fluctuations ${ }^{4 \theta}$. This is presumably comparable to the means by which field conditions permit plants to survive and prosper under a range of variables to which they would succumb in the laboratory.

The random week-to-week fluctuations observed throughout the ten years are, for the most part, not capable of interpretation. The causes of a few are, however, known. The sudden drop in the 179th to 181st passages is such a one. This almost resulted in loss of the entire clone, for in the 181st passage, out of the 25 cultures only a single one, No. 12, survived. The entire clone was recovered and re-established from this single root tip, and even in this case the primary tip and all six of the secondary tips were killed, the meristem being recovered from nine newly established tertiaries. The cause of this near-tragedy was traced to a split in the condenser tube of the still used in preparing distilled water, allowing tap water to pass into the supposedly pure water supply. This was not city water but came from deep wells. The toxic agent is not definitely known but was probably a trace of lubricating oil shown to be present in the laboratory water supply in considerable quantity. When this condition was corrected the cultures recovered rapidly, and by the 184 th passage had been built up to full number (25) and a normal increment rate $(5 \cdot 3 \mathrm{~mm}$. as against the idealized average for that time of year of $c a \cdot 6 \cdot 6 \mathrm{~mm}$.). The sudden drop in the 228 th passage was correlated with and probably the result of a very sharp drop in room temperature ${ }^{48}$, such as sometimes occurs in mid-September. The windows of the laboratory had been left open follow. ing a very hot day, and a sudden fall in outdoor temperature was paralleled by that indoors, resulting in thorough chilling and excessive condensation on the walls of the flasks. Recovery from this was as abrupt as its incidence. The low general level between passages 279 and 287 coincided with a period of illness during which the clone was maintained by a relatively inexperienced assistant. The low level between passages 372 and 409 occurred in a period when the concentration of iron had been reduced as a result of experiments later shown to have been misinterpreted ${ }^{92}$. The sudden fall in passage 425 resulted from the accidental omission of iron from one batch of nutrient. Other fluctuations are, how. ever, unexplained.

The clone is still in excellent condition and shows every evidence of potential immortality. Cultures of this stock have been sent to the University of Missouri, the California Institute of Technology, New York University and Connecticut College, where they have been maintained through various periods, for special studies and for comparison with other elones of tomato roots.

Since this note is chiefly historical in import, I have appended a chronological bibliography of all papers dealing with the cultivation of excised root tips that have come to my attention, which gives, better than could any but a very extended discussion, a panoramic view of the development of this branch of plant tissue culture. I have purposely omitted references dealing exclusively with the cultivation of other tissues or organs, except for a few of the very early background papers, since these represent a separate though closely related field.

\section{CHRONOLOGICAL BIBLIOGRAPHY}

\section{2}

1. Haberlandt, G., Kulturversuche mit isolierten"Pflanzenzellen, Sitzungsber. Akad. Wiss. Wien, Math.Naturw. Kl., 111, 69-92 (1902).

2. Winkler, H., Besprechung der Arbeit G. Haberlandt's "Culturversuche mit isolierten Pflanzenzellen", Bot. Z., 60, 262-264 (1902).

\section{9}

3. Knudson, L., Viability of detached root-cap cells, Amer. J. Bot., 6, 309-310 (1919).

\section{2}

4. Kotte, W., Kulturversuche mit isolierten Wurzel. spitzen, Beitr. allg. Bot., 2, 413-434 (1922).

5. Kotte, W., Wurzelmeristem in Gewebekultur, Ber. bot. Gesel., 40, 269-272 (1922).

6. Robbins, W. J., Cultivation of excised root tips and stem tips under sterile conditions, Bot. Gaz., '73, 376-390 (1922).

7. Robbins, W. J., Effect of autolyzed yeast and peptone on growth of excised corn root tips in the dark, Bot. Gaz., 74, 59-79 (1922).

\section{3}

8. Chambers, W. H., Cultures of plant cells, Proc. Soc. Exp. Biol. and Med., 21, 71-72 (1923).

9. Robbins, W. J., and Maneval, W. E., Further experiments on growth of excised root tips under sterile conditions, Bot. Gaz., 76, 274-287 (1923).

\section{4}

10. Chambers, W. H., Tissue culture of plants, J. Missouri State Med. Assoc., 21, 55-56 (1924).

11. Robbins, W. J., and Maneval, W. E., Effect of light on growth of excised root tips under sterile conditions, Bot. Gaz., 78, 424-432 (1924).

\section{9}

12. Mayer, G. G., Der Einfluss Nährstoffzuführung auf das Längewachstum isolierter Wurzeln, Diss., Giessen (1929).

\section{0}

13. Dauphiné, A., Caractères histologiques de racines développées isolément, C.R. Acad. Sci., Paris, 190, $1318-1320(1930)$.

\section{1}

14. Felber-Pisk, I., Über das Wachstum isolierter Wurzeln, Sitzungsber. Akad. Wiss. Wien, Math.-Naturw. Kl., Abt. 1, 140, 67-82 (1931).

15. Heidt, K., Über das Verhalten von Explantaten der Wurzelspitze in nährstoffreien Kulturen, Arch. exp. Zellforsch., 11, 693-724 (1931).

16. White, P. R., Plant tissue cultures, the history and present status of the problem, Arch. exp. Zellforsch., 10, 501-518 (1931).

\section{2}

17. Gautheret, R. J., Sur la culture d'extremités de racines, C.R. Soc. Biol., Paris, 109, 1236 (1932). 
18. Malyschev, N., Das Wachstum des isolierten Wurzelmeristems auf sterilen Nährböden, Biol. Ztrbl., 52, 257 265 (1932).

19. Malyschev, N., The growth of isolated meristem of roots, Preslia, 11, 59-61 (1932).

20. White, P. R., Plant tissue cultures. A preliminary report of results obtained in the culturing of certain plant meristems, Arch. exp. Zellforsch., 12, 602-620 (1932).

21. White, P. R., Influence of some environmental conditions on the growth of excised root tips of wheat seodlings in liquid media, Plant Physiol., '7, 613$628(1932)$.

\section{3}

22. Gautherer, R. J., Cultures de méristèmes de racines de Zea Mays, C.R. Acad. Sci., Paris, 19\%, 85 (1933).

23. Lewis, K. H., and McCoy, E., Root nodule formation on the garden bean, studied by a technique of tissue culture, Bot. Gaz., 95, 316-329 (1933).

24. White, P. R., Concentrations of inorganic ions as related to growth of excised root tips of wheat seedlings, Plant Physiol., 8, 489-508 (1933).

25. White, P. R., The .SH radical and some other sources of sulfur as affecting growth of isolated root tips of wheat seedlings, Protoplasma, 19, 132-135 (1933).

26. White, P. R., Liquid media as substrata for the culturing of isolated root tips, Biol. Ztrbl., 53, 359-364 (1933).

\section{4}

27. Galligar, G. C., Growth studies on excised root tips, Diss., Univ. Illinois (1934).

28. White, P. R., Po entially unlimited growth of excised tomato root tips in a liquid medium, Plant Physiol., 9, 585-600 (1934).

29. White, P. R., Multiplication of the viruses of tobacco and aucuba mosaics in growing excised tomato root tips, Phytopath., 24, 1003-1011 (1934).

\section{5}

30. Gautheret, R. J., Recherches sur la culture des tissus végétaux. Essajs de culture de quelques tissus méristèmatiques, Thèse, Univ. Paris (1935).

31. Loo, T. L., and Loo, S. W., Studies on the culture of isolated root tips under sterile conditions. 1 . The effect of leaf extract on the growth of root tips, Sci. Rep. Nat. Cent. Univ. Nanking, Ser. B, Biol., 2, 51-79 (1935).

\section{6}

32. Fiedler, H., Entwicklungs- und reizphysiologische Untersuchungen an Kulturen isolierter Wurzelspitzen, Zeitschr. Bot., 30, 385-436 (1936).

33. Galligar, G. C., Influence of certain organic substances upon the growth behavior of excised root tips, Trans. Ill. Acad. Sci., 29, 59-68 (1936).

34. Geiger-Huber, M., Der Einfluss des Wuchshormons (Heteroauxin) auf das Wurzelwachstum, Verh. schweiz. Naturf. Gesel., 1936, 313 (1936).

35. Geiger-Huber, M., u. Burlet, E., Úber den hormonalen Einfluss der $\beta$-indolylessigsäure auf da; Wachstum isolierter Wurzeln in keimfreier Organkultur, Jahrb. wiss. Bot., 84, 233-253 (1936).

36. Loo, T. L., and Loo, S. W., Studies on the culture of isolated root tips under sterile conditions. II. Further experiments on the effects of leaf extract on growth of root tips, Chinese J. Exp. Biol., 1, 189-206 (1936).

37. Nagao, M., Studies on the growth hormones of plants. I. The production of growth substance in root tips, Sci. Rep. Tôhoku Univ. (Biol.), 10,721-731 (1936),

38. Robbins, W. J., Bartley, M. A., and White, V. B., Growth of fragments of excised root tips, Bot. Gaz., 97, 554-579 (1936).
39. Robbins, W. J., White, V. B., McClary, J. E., and Bartley, M., The importance of ash elements in the cultivation of excised root tips, Proc. Nat. Acad. Sci., Wash., 22, 636-639 (1936).

\section{7}

40. Bonner, J., Vitamin $B_{1}$ a growth factor for higher plants, Science, 85, 183-184 (1937).

41. Bonner, J., and Addicott, F., Cultivation in vitro of excised pea roots, Bot. Gaz., 99, 144-170 (1937).

42. Nagao, M., Studies on the growth hormones of plants. III. The occurrence of growth substance in isolated roots grown under sterilized conditions, Sci. Rep. Tôhoku Univ. (Biol.), 12, 191-193 (1937).

43. Robbins, W. J., and Bartley, M. A., Vitamin $B_{1}$ and the growth of excised tomato roots, Science, 85, 246-247 (1937).

44. Robbins, W. J., and Bartley, M. A., Use of dextrose by excised tomato roots, Science, 86, 290-291 (1937).

45. Robbins, W. J., and Bartley, M. A., Thiazole and the growth of excised tomato roots, Proc. U.S. Nat. Acad. Sci., 23, 385-388 (1937).

46. Robbins, W. J., and White, V. D., Effects of extracts from the corn plant on growth of excised root tips, Bot. Gaz., 98, 520-534 (1937).

47. Robbins, W. J., and White, V. D., Limited growth and abnormalities in excised corn root tips, Bot. Gaz., 98, 209-242 (1937).

48. White, P. R., Seasonal fluctuations in growth rates of excised tomato root tips, Plant Physiol., 12, 183190 (1937).

49. White, P. R., Survival of isolated tomato roots at suboptimal and supraoptimal temperatures, Plant Physiol., 12, 771-776 (1937).

50. White, P. R., Separation from yeast of materials essential for growth of excised tomato roots, Plant Physiol., 12, 777-791 (1937).

51. White, P. R., Amino-acids in the nutrition of excised tomato roots, Plant Physiol., 12, 793-802 (1937).

52. White, P. R., Vitamin $B_{1}$ in the nutrition of excised tomato roots, Plant Physiol., 12, 803-811 (1937).

53. White, P. R., A comparison of nutrient salt solutions for the cultivation of excised tomato roots, Growth, $1,182-188(1937)$.

\section{8}

54. Addicott, F. T., and Bonner, J., Nicotinic acid and the growth of isolated pea roots, Science, 88, 577578 (1938).

55. Bonner, J., Thiamin (vitamin $B_{1}$ ) and the growth of roots : the relation of chemical structure to physiological activity, Amer. J. Bot., 25, 543-549 (1938).

56. Bonner, J., and Buchman, E. R., Syntheses carried out in vitro by isolated pea roots. I., Proc. U.S. Nat. Acad. Sci., 24, 431-438 (1938).

57. Delarge, L., Cultures de méristèmes radiculaires in vitro. Les variations individuelles et leur significa. tion physiologique, Bull. Soc. Roy. Bot. Belg., r1, 73-88 (1938).

58. Galligar, G. C., Correlation between growth of excised root tips and types of food stored in the seed, Plant Physiol., 13, 599-609 (1938).

59. Nagao, M., Studies on the growth hormones of plants. IV. Further experiments on the production of growth substance in root tips, Sci. Rep. Tôhoku Univ. (Biol.), 13, 221-228 (1938).

60. van Overbeek, J., and Bonner, J., Auxin in isolated roots growing in vitro, Proc. U.S. Nat. Acad. Sci., 24, 260-264 (1938).

61. Robbins, W. J., and Schmidt, M. B., Growth of excised roots of the tomato, Bot. Gaz., 99, 671-728 (1938).

62. Stanley, W. M., Aucuba mosaic virus protein isolated from diseased, excised tomato roots grown in vitro, J. Biol. Chem., 126, 125-131 (1938). 
63. White, P. R., "Root pressure"-an unappreciated force in sap movement, Amer. J. Bot., 25, 223-227 (1938).

64. White, P. R., Accessory salts in the nutrition of excised tomato roots, Plant Physiol., 13, 391-398 (1938).

65. White, P. R., Cultivation of excised roots of dicotyledonous plants, Amer. J. Bot., 25, 348-356 (1938).

\section{9}

66. Addicott, F. T., Vitamin $B_{1}$ in relation to meristematic activity of isolated pea roots, Bot. Gaz., 100, 836$843(1939)$.

67. Addicott, F. T., and Devirian, P. S., A second growth factor for excised pea roots : nicotinic acid, Amer. J. Bot., 26, 667-671 (1939).

68. Bonner, J., and Devirian, P. S., Growth factor requirements of four species of isolated roots, Amer. J. Bot., 26, 661-665 (1939).

69. Delarge, L., Cultures de méristèmes radiculaires in vitro. Les milieux réputés complets et les variations individuelles, Bull. Soc. Roy. Bot. Belg., 71, 145162 (1939).

70. Delarge, L., Croissance et ramification des racines cultivées isolément, Bull. Soc. Roy. Sci. Liége, 1939, 397-416 (1939).

71. Galligar, G. C., Growth behavior of one-millimeter excised root tips, Plant Physiol., 14, 163-169 (1939).

72. van Overbeek, J., Evidence for auxin production in isolated roots growing in vitro, Bot. Gaz., 101, 450456 (1939).

73. Robbins, W. J., Thiamin and plant growth, Science, 89, 303-307 (1939).

74. Robbins, W. J., and Schmidt, M. B., Vitamin $\mathrm{B}_{6}$, a growth substance for excised tomato roots, Proc. U.S. Nat. Acad. Sci., 25, 1-3 (1939).

75. Robbins, W. J., and Schmidt, M. B., Further experiments on excised tomato roots, Amer. J. Bot., 26, 149-159 (1939).

76. Robbins, W. J., and Schmidt, M. B., Growth of excised tomato roots in a synthetic solution, Bull. Torrey Bot. Club, 66, 193-200 (1939).

77. White, P. R., Glycine in the nutrition of excised tomato roots, Plant Physiol., 14, 527-538 (1939).

\section{0}

78. Bonner, J., On the growth factor requirements of isolated roots, Amer. J. Bot., 2\%, 692-701 (1940).

79. Bonner, J., Specificity of nicotinic acid as a growth factor for isolated pea roots, Plant Physiol., 15, $553-557(1940)$

80. Robbins, W. J., Response of excised tomato roots to $\beta$ (-4-methylthiazolyl-5)-alanine, Plant Physiol., 15, $547-552$ (1940).

81. White, P. R., Does "C. P. grade" sucrose contain impurities significant for the nutrition of excised tomato roots ?, Plant Physiol., 15, 349-354 (1940).

82. White, P. R., Sucrose vs. dextrose as carbohydrate source for excised tomato roots, Plant Physiol., 15, 355-358 (1940).

83. White, P. R., Vitamin $B_{6}$, nicotinic acid, pyridine, glycine and thiamin in the nutrition of excised tomato roots, Amer. J. Bot., 2\%, $811-821$ (1940).

\section{1}

84. Addicott, F. T., Effects of root growth hormones on the meristem of excised pea roots, Bot. Gaz., 102, 576-581 (1941).

85. Day, Dorothy, Vitamin $\mathrm{B}_{6}$ and growth of excised tomato roots in agar culture, Science, 94, 468-469 (1941).

86. Robbins, W. J., Growth of excised roots and heterosis in tomato, Amer. J. Bot., 28, 216-225 (1941).

\section{2}

87. Bonner, J., Culture of isolated roots of Acacia melanoxylon, Bull. Torrey Bot. Club, 69, 130-133 (1942).

88. Bonner, J., Riboflavin in isolated roots, Bot. Gaz., 103, 581-585 (I942).

89. Bonner, J., A reversible growth inhibition of isolated tomato roots, Proc. U.S. Nat. Acad. Sci., 28, 321-324 (1942).

90. Robbins, W. J., Specificity of pyridoxine for excised tomato roots, Amer. J. Bot., 29, 241-245 (1942).

\section{3}

91. White, P. R., Further evidence on the significance of glycine, pyridoxine and nicotinic acid in the nutrition of excised tomato roots, Amer. J. Bot., 30, $33-36$ (1943).

92. White, P. R., Nutrient deficiency studies and an improved inorganic nutrient for cultivation of excised tomato roots, Growth, in the Press.

93. White, P. R., The osmotic vs. the respiratory role of sucrose in the nutrition of excised tomato roots, Growth, in the Press.

94. White, P. R., "A Handbook of Plant Tissue Culture" (Lancaster, Pa.: The Jaques Cattell Press, 1943).

\section{THE ROTHAMSTED CENTENARY}

TN spite of the difficulties arising out of the War, an 1 impressive gathering assembled at Rothamsted on July 21 to take part in the commemoration of its hundred years of uninterrupted work in agricultural science. There have been several similar occasions in the history of the Station, when the leading figures in the agricultural world have been glad to testify to the value of its activities. The first was in 1855 , when a new laboratory building was formally handed over to Lawes and Gilbert as a testimonial from British farmers in recognition of twelve years pioneering work. The second was the jubilee of the Rothamsted Experiments, celebrated in 1893, when the experiments, having completed fifty years; had left their mark not only on home farming but also on settled agriculture over a much wider area. Now, after the passage of a further fifty years, we were witnessing another ceremony-not, of course, on the international scale which would have been appropriate in normal times, but none the less a very outstanding demonstration of the high regard in which the past and present work of the Station is held in scientific and agricultural circles. Lord Radnor, chairman of the Lawes Agricultural Trust, presided, and the Right Hon. R. S. Hudson, Minister of Agriculture, received a special welcome from the three hundred guests representing various scientific societies and al sides of the agricultural and allied industries. Repre. sentatives, diplomatic, scientific and agricultural, from twenty-eight countries were present.

Welcoming the guests, Lord Radnor recalled some of the main facts in the history and achievement of the Station, and said that the completion of the first century of work coincided with the coming retirement of Sir John Russell and the appointment of Dr. W. G. Ogg, of the Macaulay Institute of Soil Research, Aberdeen, as director. In his speech, the Minister of Agriculture pointed out how the proper use of fertilizers so firmly based on Rothamsted work from its earliest days is now more than ever essential in the food production campaign. He gave as an example the key position of superphosphate--the first great practical outcome of Lawes' experiments- 